\title{
Effects of an Auxin and a brassinosteroid on physical, chemical and biochemical attributes of 'Galaxy' apples
}

\section{Ângela Preza Ramosi ${ }^{*}$ (iD Aquidauana Miqueloto Zanardi ${ }^{2}$ Cassandro Vidal Talamini do Amarante ${ }^{3}$ Cristiano André Steffens ${ }^{3}$ Adaucto Bellarmino Pereira-Netto ${ }^{4}$}

${ }^{1}$ Centro de Ciências Agroveterinárias (CAV), Universidade do Estado de Santa Catarina (UDESC), 88520-000, Lages, SC, Brasil. E-mail: ramosangelapreza@gmail.com. *Corresponding author.

${ }^{2}$ Departamento de Agronomia, Instituto Federal de Santa Catarina (IFSC), São Miguel do Oeste, SC, Brasil.

${ }^{3}$ Departamento de Produção Vegetal, Centro de Ciências Agroveterinárias (CAV), Universidade do Estado de Santa Catarina (UDESC), Lages, SC, Brasil. ${ }^{4}$ Departamento de botânica, Setor de Ciências biológicas (SCB), Universidade Federal do Paraná (UFPR), Curitiba, PR, Brasil.

ABSTRACT: The aim of this study was to study the effect of the auxin naphthalene acetic acid (NAA) and the brassinosteroid 28-homocastasterone (28-HCS) applied every 15 days (harvest 2015/16) or every 21 days (harvest 2016/17) after full bloom, on the physical, chemical and biochemical attributes of the 'Galaxy' apples. The study was performed at a commercial orchard at Vacaria county, Rio Grande do Sul State, Brazil. The following treatments were applied: water (control), NAA (0.1\%), 28-HCS $\left(10^{-6} \mathrm{M}\right)$ and NAA (0.1\%) + 28-HCS (10-6 M). For this purpose, $300 \mu \mathrm{L}$ of the plant growth regulator solutions were applied to the fruit peduncles. Fruits treated with NAA every 21 days presented higher starch-iodine index and lower total soluble solids (TSS), titratable acidity (TA), lightness index (L) and hue angle $\left(h^{\circ}\right)$ than 28-HCS-treated fruits. Fruits treated every 15 days with NAA presented reduced skin rupture force (SRF), total antioxidant activities (TAA) of the skin and flesh, and hydrogen peroxide content compared to the control fruits. In addition, NAA application every 15 and 21 days resulted in increased anthocyanin content in the skin. Application of NAA $+28-H C S$ reduced superoxide dismutase activity. 28-HCS applications increased TSS, color attributes $\left(C\right.$ and $h^{\circ}$ ) of the skin, total antioxidant activity of the skin and flesh and peroxidase activity compared to control fruits. These results are expected to help to understand how plant growth regulators affect apple quality. In addition, results described here are also expected to help on the development of strategies to reduce post harvest losses and to increase fruit shelf life.

Key words: Malus domestica, phytohormone, 28-homocastasterone (28-HCS), naphthalene acetic acid.

Ação da auxina e do brassinosteroide nos atributos físico-químicos e bioquímicos de maçãs 'Galaxy'

RESUMO: $O$ objetivo deste estudo foi avaliar a ação do ácido naftaleno acético (ANA) e do brassinosteroide (catasterona), aplicados a cada 15 (safra 2015/16) ou 21 (safra 2016/17) dias a partir dos 40 dias após a plena floração, nos atributos físico-químicos e bioquímicos de maçãs 'Galaxy'. O estudo foi realizado em um pomar comercial de macieiras 'Galaxy' no município de Vacaria, RS. Os tratamentos avaliados foram: água (controle), ANA $(0,1 \%)$, catasterona $\left(10^{-6} \mathrm{M}\right)$ e ANA $(0,1 \%)+$ catasterona $\left(10^{-6} \mathrm{M}\right)$. As aplicações foram realizadas no pedúnculo dos frutos, utilizando $300 \mu \mathrm{L}$ de solução por pedúnculo. Frutos tratados com ANA a cada 21 dias tiveram maior índice de iodo-amido e menores valores de sólidos solúveis (SS), acidez titulável e dos atributos de cor L e ângulo hue $\left(h^{\circ}\right)$ do que os frutos tratados com catasterona. Aplicações de ANA a cada 15 dias reduziu a força de ruptura da casca (FRC), atividade antioxidante (AAT) da casca, da polpa e conteúdo de peróxido de hidrogênio. Além disso, ANA aplicada a cada 15 ou 21 dias aumentaram o teor de antocianinas na casca. ANA + catasterona reduziu a atividade da enzima superóxido dismutase. Entretanto, aplicações de catasterona a cada 15 dias aumentou o teor de SS, atributos de cor $\left(\mathrm{C}\right.$ e $\left.\mathrm{h}^{\circ}\right)$ na casca, atividade antioxidante da casca e da polpa, compostos fenólicos totais (CFT) e atividade da enzima peroxidase dos frutos de maçãs. Portanto, estudos adicionais devem ser realizados para confirmar a ação desses fitorreguladores na manutenção da qualidade e redução das perdas pós-colheitas de maçãs 'Galaxy'.

Palavras-chave: Malus domestica Borkh., fitormônio, 28-homocatasterona (28-HCS), ácido naftaleno acético.

\section{INTRODUCTION}

The apple Malus domestica is of great economic importance worldwide (THEWES et al., 2015). The southern part of Brazil is the largest apple producing area in the country, being the counties of Vacaria, in the Rio Grande do Sul State, São Joaquim and Fraiburgo, in Santa Catarina State and Palmas, in Paraná State, the top producers in the country (PETRI et al., 2011). In southern Brazil, apple production is essentially limited to two cultivars, Gala and Fuji (THEWES et al., 2015), which present high postharvest losses, due to a combination of physiological disorders, mechanical damage and fruit senescence. 
Due to the high post-harvest losses and the escalating demand for high quality fruits, new crop management techniques are being investigated in order to ensure quality and to increase post-harvest life of the fruits. Phytoregulators (also known as plant growth regulators) present potential to contribute to preserve fruit quality and to increase shelf life of fruits. Phytoregulators are chemical messengers that actively participate in cell division, elongation and differentiation (BALBI et al., 2003; MOTERLE et al., 2011), controlling physiological and biochemical features of fruits such as fruit color, ethylene production and enzyme activity.

Among the phytoregulators, auxins and brassinosteroids present potential to help to maintain fruit quality and to improve post-harvest conservation. MIQUELOTO (2014) demonstrated that naphthalene acetic acid (NAA) applied at $10 \mathrm{mg}$ $\mathrm{L}^{-1} 50$ days after full bloom (DAFB) of 'Braeburn' apples significantly increased fruit size through the increase in the number and size of parenchymal tissue cells of the flesh. Miqueloto (2014) also demonstrated that NAA, when applied between 50 and 106 DAFB, decreased respiration rate and ethylene production of 'Braeburn' apple trees, keeping high levels of total soluble solids and titratable acidity of the fruits.

Castasterone and brassinolide induce important plant growth-related physiological responses. Both castasterone and brassinolide are polyhydroxysteroid lactones from the new plant hormone class called brassinosteroids (BRs) (YOKOTA, 1997). These plant hormones may stimulate genes that encode enzymes responsible for the increase in the cell number and size, as well as plant flowering (TAIZ \& ZEIGER, 2013). In addition, BRs boost both the fruiting capacity of plants, and the antioxidant activity that supports the maintenance of fruit quality (NAGATA et al., 2001). The BRs also protect plants and fruits from biotic and abiotic stresses (LIU et al., 2018). Although, BRs are very important for plants, only a few studies have been performed to study their effect on antioxidative stress enzymes, hydrogen peroxide radical level, antioxidant activity and content of phenolic compounds and anthocyanin in fruits. Therefore, we carried out this study in order to evaluate the effects of naphthalene acetic acid (NAA) and the brassinosteroid 28-homocastasterone (28-HCS), applied every 15 or 21 days after full bloom, on physical, chemical and biochemical attributes of 'Galaxy' apples. Findings described here may help to understand the effects these two phytoregulators on apple quality and also help on the development of strategies to reduce post-harvest losses and increase shelf life of apple fruits.

\section{MATERIALS AND METHODS}

This study was carried out at a 'Galaxy' apple commercial orchard grafted on 'Marubakaido' rootstock, using a 'M9' filter in the Vacaria county, Rio Grande do Sul State, Brazil (28 28' 11.50" S and $50^{\circ} 48^{\prime} 47.12$ " W, $946 \mathrm{~m}$ altitude). Apple trees were conducted in a central leader system, with a spacing of $4 \times 0.72 \mathrm{~m}$, and covered with black hail net $(7 \times 4 \mathrm{~mm}$ mesh). 'Galaxy' apple fruit peduncles were painted with $300 \mu \mathrm{L}$ of naphthalene acetic acid (NAA, $0.1 \%$ ), 28 -homocastasterone (28-HCS, $\left.10^{-6} \mathrm{M}\right)$, NAA $(0.1 \%)$ +28 -HCS $\left(10^{-6} \mathrm{M}\right)$ and distilled water (control) every 15 days (harvest 2015/2016) or 21 days (harvest 2016/2017), between 40 and 127 DAFB.

Fruits were analyzed for skin color, flesh firmness and texture attributes, iodide-starch index, titratable acidity (TA), and total soluble solids (TSS) at 136 (harvest 2015/16) and 132 (harvest 2016/17) DAFB, as well as total phenolic compounds (TPC), total antioxidant activity (TAA), total anthocyanins and hydrogen peroxide $\left(\mathrm{H}_{2} \mathrm{O}_{2}\right)$. Lipid peroxidation, peroxidase (POD) and superoxide dismutase (SOD) activities were also assessed but at the 2015/16 harvest only.

Fruit skin was analyzed for hue angle $\left(h^{\circ}\right)$, lightness (L) and chroma $(\mathrm{C})$ system using a Minolta CR 400 colorimeter (Konica Minolta Inc., Tokyo, Japan). Measurements were carried out at the equatorial zone of the fruits, on the side most and less exposed to the sun. Flesh firmness (N) was evaluated using an electronic penetrometer (GÜSS Manufacturing Ltd., South Africa) on both sides of the fruit, in the equatorial zone.

Texture attributes $(\mathrm{N})$ were determined with the Texture analyzer TAXT Plus ${ }^{\circledR}$ model (Stable Micro Systems Ltd., Surrey, UK), using a PS2 model probe, with a $2 \mathrm{~mm}$ tip. The tip was inserted into the flesh until a $5 \mathrm{~mm}$ depth with pre-test, test and posttest speeds of 30,5 and $30 \mathrm{~mm} \mathrm{~s}^{-1}$, respectively.

The starch-iodine index was determined using a metal iodine and potassium iodide solution. Fruits were cut along the largest diameter and the resulting cuts were dipped into the metal iodine and potassium iodide solution for $2 \mathrm{~min}$. Afterwards, starch staining was recorded and scored on a 1-5 scale, according to WERNER (1989), as following: $1=$ fully green fruits (low starch degradation) and $5=$ fruits with a high degree of maturation (high starch degradation).

TA [Malic acid content (\%)] was determined by titration. For this purpose, $10 \mathrm{~mL}$ juice sample diluted in $90 \mathrm{~mL}$ of distilled water, using a 
$0.1 \mathrm{~N} \mathrm{NaOH}$ solution to reach $\mathrm{pH}$ 8.1. Total soluble solids content (\%) was determined using a digital refractometer (model PR201 $\alpha$, Atago, Tokyo, Japan), using correction for temperature $\left(20^{\circ} \mathrm{C}\right)$.

Total antioxidant activity (TAA) and concentration of total phenolic compounds (TPC) were determined for fruit skin and flesh. Fruits were peeled (1-2 mm thick) and both skin and flesh were frozen, separately, in liquid nitrogen. Afterwards, 5 $\mathrm{g}$ of flesh and $2.5 \mathrm{~g}$ of fruit skin were fully macerated in liquid nitrogen. After that, $25 \mathrm{~g}$ of the extract from the skin or flesh was placed in a glass tube containing $40 \mathrm{~mL}$ of $50 \%$ methanol, and centrifuged at $15,000 \mathrm{rpm}$ for 15 minutes. The supernatant was withdrawn and stored. After, $40 \mathrm{~mL}$ of $70 \%$ acetone was added to the first extraction pellet and homogenized. Following a 60 minutes rest at room temperature the homogenate was centrifuged at $15,000 \mathrm{rpm}$ for 15 minutes. The supernatant was once again collected and transferred to a volumetric flask in which the first supernatant was stored and the volume filled up with deionized water until reached $100 \mathrm{~mL}$. The resulting extract was used for TAA and TPC determination. The TAA was determined using ABTS [2,2'-azino-bis (3-ethylbenzothiazolin) 6-sulfonic acid] according to RE and co-workers (1999), with the help of a microplate reader (EnSpire model, PerkinElmer) at $734 \mathrm{~nm}$ wavelength. Results were expressed as Trolox equivalent antioxidant activity (TEAC, $\mu \mathrm{Mol}$ of trolox equivalents per 100 $\mathrm{g}$ of fresh sample weight). The TPC was determined using the Folin-Ciocalteu method, with the help of a microplate reader operating at a $765 \mathrm{~nm}$ wavelength. The results were expressed in $\mathrm{mg}$ equivalents of gallic acid per $100 \mathrm{~g}$ of fresh sample weight $(\mathrm{mg}$ EAG $100 \mathrm{~g}^{-1} \mathrm{FW}$ ).

Total anthocyanins (TAN) were determined according to FULEKI and FRANCIS (1968), with the help of a microplate reader at the $535 \mathrm{~nm}$ wavelength. TAN was expressed in $\mathrm{mg}$ of cyanidin 3-glycoside per $100 \mathrm{~g}$ fresh weight.

The $\mathrm{H}_{2} \mathrm{O}_{2}$ determination was performed according to the method proposed by HERMESLIMA et al. (1995). Readings were compared to a $\mathrm{H}_{2} \mathrm{O}_{2}$ standard curve and results expressed in $\mu \mathrm{mol} \mathrm{g} \mathrm{g}^{-1}$ of fresh weight. Determination of lipid peroxidation in cell membranes was performed according to the method described by HEATH and PACKER (1968). Results were expressed in $\mathrm{nmol} \mathrm{g}^{-1} \mathrm{FW}$ of malondialdehyde (MDA) formed.

Peroxidase (POD) and superoxide dismutase (SOD) activities were determined according to KAR and MISHRA (1976) and DEL
LONGO and co-workers (1993), with modifications. The POD activity was determined after a 1 minute reaction, with the help of a microplate reader wavelength $(420 \mathrm{~nm})$ and expressed in $\mu \mathrm{mol} \mathrm{min}{ }^{-1}$ $\mathrm{mg}^{-1}$ of protein. The SOD activity was performed at $25^{\circ} \mathrm{C}$ in a reaction chamber, under light provided by a $15 \mathrm{~W}$ fluorescent lamp located inside the reaction chamber. After 10 min of exposure to light, the lamp was turned off and the amount of the blue compound produced by the reduction of Nitro Blue Tetrazolium (NBT) was quantified using a microplate reader at the wavelength of the $560 \mathrm{~nm}$. The activity was expressed

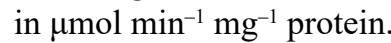

The randomized block design for 4 treatments and 5 replicates (4 plants with 50 fruits per plant) was used for the experiments. Data were submitted to the Bartlett test (BARTLETT, 1937) and to the Shapiro-Wilk test (SHAPIRO \& WILK, 1965) to confirm homogeneity of the variances and normality of the residues, respectively. After confirmation of a normal model, data were submitted to the analysis of variance (ANOVA). Afterwards means were compared by the Tukey test $(P<0.05)$. All the analyses were performed using the statistical software SAS, version 9.1 (SAS INSTITUTE, 2009).

\section{RESULTS AND DISCUSSION}

This study demonstrated the effect of NAA and 28-HCS several physical, chemical and biochemical attributes of 'Galaxy' apples. No statistically significant difference was reported for the iodo-starch index in the fruits treated every 15 days with NAA, 28-HCS or NAA + 28-HCS (Table 1). However, compared to both control and NAA + 28-HCS treatments, higher iodine-starch index was observed for fruits treated with NAA every 21 days and harvested at 132 DAFB (Table 1). These results might indicate that NAA application raises the starch degradation rate, most likely because of the increased ethylene output and the enhanced activity of hydrolytic enzymes responsible for breaking down starch. This hypothesis is supported by findings by YU and YANG (1979), who confirmed an escalation in the conversion of methionine to ethylene and high activity of hydrolytic enzymes in the vegetable tissues that were subjected to NAA application.

Fruits treated with NAA every 15 or 21 days exhibited lower TSS than those treated with 28HCS (Table 1). The TSS is an estimate of the amount of sugars and organic acids present in fruits, which are responsible for taste and acceptance of fruits by the consumers. During ripening, TSS level increases and 
Table 1 - The starch-iodine content, total soluble solids (TSS), titratable acidity (TA; \% malic acid) in the 'Galaxy' apple fruits treated every 15 or 21 days with $0.1 \%$ naphthalene acetic acid (NAA), 28-homocatasterone (28-HCS) $10^{-6} \mathrm{M}$ and NAA $0.1 \%+28$ homocatasterone (28- HCS) $10^{-6} \mathrm{M}$ and harvested at 136 and 132 days after full bloom (DAFB) in the 2015/16 and 2016/17 harvest, respectively.

\begin{tabular}{|c|c|c|c|c|c|c|}
\hline \multirow[t]{2}{*}{ Treatment } & \multicolumn{2}{|c|}{ Index of iodine-starch (1-5) } & \multicolumn{2}{|c|}{--- } & \multicolumn{2}{|c|}{---TA (\% malic acid)-- } \\
\hline & 2016 & 2017 & 2016 & 2017 & 2016 & 2017 \\
\hline Control & $4.26 \mathrm{a}$ & $2.06 \mathrm{~b}$ & $10.00 \mathrm{ab}$ & $9.93 \mathrm{a}$ & $0.64 \mathrm{a}$ & $0.66 \mathrm{a}$ \\
\hline NAA $0.1 \%$ & $4.10 \mathrm{a}$ & $3.62 \mathrm{a}$ & $9.58 \mathrm{~b}$ & $9.55 \mathrm{~b}$ & $0.63 \mathrm{a}$ & $0.63 \mathrm{~b}$ \\
\hline 28 -HCS $10^{-6} \mathrm{M}$ & $4.22 \mathrm{a}$ & $2.70 \mathrm{~b}$ & $10.78 \mathrm{a}$ & $10.12 \mathrm{a}$ & $0.64 \mathrm{a}$ & $0.67 \mathrm{a}$ \\
\hline NAA $0.1 \%+28-\mathrm{HCS} 10^{-6} \mathrm{M}$ & $4.50 \mathrm{a}$ & $2.55 \mathrm{~b}$ & $10.13 \mathrm{ab}$ & $9.43 \mathrm{~b}$ & $0.63 \mathrm{a}$ & $0.63 \mathrm{~b}$ \\
\hline Coefficient of variation (\%) & 8.37 & 23.87 & 5.46 & 7.35 & 3.11 & 3.38 \\
\hline
\end{tabular}

Means followed by the same letter in the columns do not differ significantly by the Tukey test $(\mathrm{P}<0.05)$.

therefore, it can be used as a physiological indicator for right harvesting time and fruit quality. The XU and co-workers (2015) observed that 24-Epibrassinolide (EBR), a brassinosteroid, significantly increased soluble sugar content in grape berries, being the effect attributed to the ability of BRs to regulate some physiological processes in plants, including carbohydrate metabolism. Therefore, findings from this study suggested that 28-HCS applied at intervals of 15 and 21 days can increase TSS and thus contribute towards the maintenance of fruit quality.

Applications of NAA and 28-HCS every 15 days had no effect on the titratable acidity of the 'Galaxy' apples. However, applications of NAA and NAA+28-HCS every 21 days caused a significant reduction in TA (Table 1). Application of growth regulators like auxins, depending on the number and range of application, has been reported to decrease TA in fruits (MIQUELOTO, 2014). This decrease may be related to the increased respiratory rates in auxin-treated fruits. Breathing involves three steps: glycolysis, Krebs cycle and electron transport chain (TAIZ \& ZEIGER, 2013). Malic acid, which is the principal organic acid present in apples, may function as a substrate in the Krebs cycle. Fruits accumulate organic acids (mainly malic acid) in the vacuole. As the respiration rate increases, malic acid is withdrawn from the vacuole and imported into the mitochondrial matrix via transporters and metabolized to oxalacetate or pyruvate, which is the acetyl-CoA acceptor in the Krebs cycle (TAIZ \& ZEIGER, 2013). Thus, the Krebs cycle, as an alternative carbon pathway, uses malic acid to produce oxalacetate or pyruvate that will be used to produce NADH, FADH ${ }_{2}$ and other compounds. Therefore, it is very likely that the NAA applications induced an increase in the respiratory rate and in the consumption of organic acids in 'Galaxy' fruits, which might have resulted in the observed drop in TA.

Bi-weekly 28-HCS applications induced a higher skin rupture force (SRF) in the fruits, compared to the NAA and NAA + 28-HCS-treated fruits (Table 2). No significant effect was observed for either flesh firmness (FF) or flesh penetration force (FPF) when fruits were treated with NAA, 28HCS or NAA + 28-HCS (Table 2).

Fruits treated by-weekly with 28 -HCS, on the side most exposed to the sun, presented higher $\mathrm{C}$ and $h^{\circ}$ values than fruits treated with NAA and NAA+28-HCS, respectively. However, fruits treated with NAA every 21 days had lower $L$ and $h^{\circ}$ values compared to fruits treated with 28 -HCS (Table 3). Fruits, on the side less exposed to the sun, treated every 15 days with 28 -HCS had higher $L$ and $\mathrm{C}$ values than fruits treated with NAA and NAA + 28- HCS, respectively (Table 3). However, fruits treated with 28 -HCS every 21 days had higher values of $L$ and $h^{\circ}$ compared to fruits treated with NAA (Table 3 ).

Fruits treated with NAA every 15 or 21 days revealed a higher anthocyanin content in the skin compared to the control (not treated) fruits (Figure 1E and 1F). Anthocyanins, compounds reported in plant cell vacuoles, are the largest group of water-soluble pigments (TNAAKA et al., 2010; LIN-WANG et al., 2011). Some phytoregulators, like auxins, may stimulate anthocyanin biosynthesis, when applied to fruits. This occurs because auxins may increase gene expression or activity of some enzymes, like the chalcone synthase, that are 
Table 2 - Flesh firmness (FF), skin rupture force (SRF) and flesh penetration force (FPF) of the 'Galaxy' apple fruit treated every 15 or 21 days with $0.1 \%$ naphthalene acetic acid (NAA), 28-homocatasterone (28-HCS) $10^{-6} \mathrm{M}$ and NAA $0.1 \%+28$ homocatasterone (28- HCS) $10^{-6} \mathrm{M}$ and harvested at 136 and 132 days after full bloom (DAFB) in the 2015/16 and 2016/17 harvest, respectively.

\begin{tabular}{|c|c|c|c|c|c|c|}
\hline \multirow[t]{2}{*}{ Treatment } & \multicolumn{2}{|c|}{ 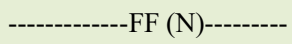 } & \multicolumn{2}{|c|}{------------SRF (N)--------- } & \multicolumn{2}{|c|}{---------FPF (N)------ } \\
\hline & 2016 & 2017 & 2016 & 2017 & 2016 & 2017 \\
\hline Control & $74.20 \mathrm{a}$ & $80.56 \mathrm{a}$ & $12.42 \mathrm{ab}$ & $12.67 \mathrm{a}$ & $3.53 \mathrm{a}$ & $3.82 \mathrm{a}$ \\
\hline NAA $0.1 \%$ & $75.47 \mathrm{a}$ & $77.00 \mathrm{a}$ & $12.05 \mathrm{~b}$ & $11.14 \mathrm{a}$ & $3.61 \mathrm{a}$ & $3.83 \mathrm{a}$ \\
\hline 28 -HCS $10^{-6} \mathrm{M}$ & $74.33 \mathrm{a}$ & $77.30 \mathrm{a}$ & $13.24 \mathrm{a}$ & $12.26 \mathrm{a}$ & $3.42 \mathrm{a}$ & $3.70 \mathrm{a}$ \\
\hline NAA $0.1 \%+28-\mathrm{HCS} 10^{-6} \mathrm{M}$ & $74.63 \mathrm{a}$ & $77.87 \mathrm{a}$ & $11.46 \mathrm{~b}$ & $11.66 \mathrm{a}$ & $3.51 \mathrm{a}$ & $3.96 \mathrm{a}$ \\
\hline Coefficient of variation $(\%)$ & 2.41 & 6.41 & 7.57 & 17.02 & 5.05 & 9.76 \\
\hline
\end{tabular}

Means followed by the same letter in the columns do not differ significantly by the Tukey test $(\mathrm{P}<0.05)$.

involved in the biosynthesis of these pigments. Not surprising, NAA application to apples resulted in increased red color of the fruit epidermis (lower $h^{\circ}$ angle) in this study. This increased red color was paralleled by enhanced anthocyanin content. Similar results were obtained by AMARANTE and co-workers (2009), leading to the conclusion that accumulation of anthocyanins resulted in lower $L$ and $h^{\circ}$ values, which triggered color change from green to red in fruits during ripening.

Fruits treated with 28-HCS bi-weekly exhibited higher total antioxidant activity (TAA) in skin and flesh than NAA-treated fruits (Figures $1 \mathrm{~A}$ and $1 \mathrm{C}$ ). However, no difference was observed for TAA in the skin of fruits treated every 21 days with 28-HCS (Figure 1B). The TAA was higher in the flesh when fruits were treated with 28-HCS every 21 days (Figure 1D). BRs are phytoregulators with the capacity to activate the antioxidant defense system of fruits (BAJGUZ, 2000; CAO et al., 2005). Fruits are constantly exposed to environmental stresses that can induce formation of reactive oxygen species (ROS) which ultimately damage the plasma membrane and cause loss quality of

Table 3 - Skin color attributes $\left(\mathrm{L}, \mathrm{C}\right.$ and $h^{\circ}$ ) on the sides, most and less exposed to the sun, in the 'Galaxy' apple fruit treated every 15 or 21 days with $0.1 \%$ naphthalene acetic acid (NAA), 28-homocatasterone (28-HCS) $10^{-6} \mathrm{M}$ and NAA $0.1 \%+28$ homocatasterone (28-HCS) $10^{-6} \mathrm{M}$ and harvested at 136 and 132 days after full bloom (DAFB) in the 2015/16 and 2016/17 crops, respectively.

\begin{tabular}{|c|c|c|c|c|c|c|}
\hline \multirow[t]{2}{*}{ Treatment } & \multicolumn{3}{|c|}{----------------------'2015/2016--------------- } & \multicolumn{3}{|c|}{-----------------------2016/2017-------------- } \\
\hline & $L$ & $C$ & $h^{o}$ & $L$ & $C$ & $h^{o}$ \\
\hline Control & $49.4 \mathrm{a}$ & $36.8 \mathrm{ab}$ & $40.7 \mathrm{a}$ & $52.6 \mathrm{a}$ & $36.4 \mathrm{a}$ & $42.4 \mathrm{a}$ \\
\hline NAA $0.1 \%$ & $46.6 \mathrm{a}$ & $35.2 \mathrm{~b}$ & $35.6 \mathrm{ab}$ & $46.8 \mathrm{~b}$ & $36.5 \mathrm{a}$ & $34.4 \mathrm{~b}$ \\
\hline $28-\mathrm{HCS} 10^{-6} \mathrm{M}$ & $48.7 \mathrm{a}$ & $38.8 \mathrm{a}$ & $37.6 \mathrm{a}$ & $52.8 \mathrm{a}$ & $37.3 \mathrm{a}$ & $41.8 \mathrm{a}$ \\
\hline NAA $0.1 \%+28-\mathrm{HCS} 10^{-6} \mathrm{M}$ & $46.8 \mathrm{a}$ & $37.9 \mathrm{ab}$ & $33.1 \mathrm{~b}$ & $50.2 \mathrm{ab}$ & $36.7 \mathrm{a}$ & $37.5 \mathrm{ab}$ \\
\hline Coefficient of variation (\%) & 5.91 & 5.8 & 13.5 & 9.02 & 5.10 & 14.97 \\
\hline \multicolumn{7}{|c|}{ - } \\
\hline Control & $70.6 \mathrm{ab}$ & $36.1 \mathrm{ab}$ & $96.1 \mathrm{a}$ & $72.3 \mathrm{ab}$ & $34.4 \mathrm{a}$ & $92.8 \mathrm{ab}$ \\
\hline NAA $0.1 \%$ & $67.6 \mathrm{~b}$ & $35.2 \mathrm{ab}$ & $92.2 \mathrm{a}$ & $67.6 \mathrm{c}$ & $33.0 \mathrm{a}$ & $82.2 \mathrm{~b}$ \\
\hline 28 -HCS $10^{-6} \mathrm{M}$ & $72.3 \mathrm{a}$ & $37.7 \mathrm{a}$ & $95.1 \mathrm{a}$ & $74.5 \mathrm{a}$ & $37.7 \mathrm{a}$ & $97.5 \mathrm{a}$ \\
\hline NAA $0.1 \%+28-\mathrm{HCS} 10^{-6} \mathrm{M}$ & $70.8 \mathrm{ab}$ & $33.5 \mathrm{~b}$ & $89.8 \mathrm{a}$ & $70.9 \mathrm{bc}$ & $33.4 \mathrm{a}$ & $87.8 \mathrm{ab}$ \\
\hline Coefficient of variation (\%) & 3.69 & 5.69 & 6.29 & 4.82 & 6.75 & 10.78 \\
\hline
\end{tabular}

Means followed by the same letter in the columns do not differ significantly by the Tukey test $(\mathrm{P}<0.05)$. 


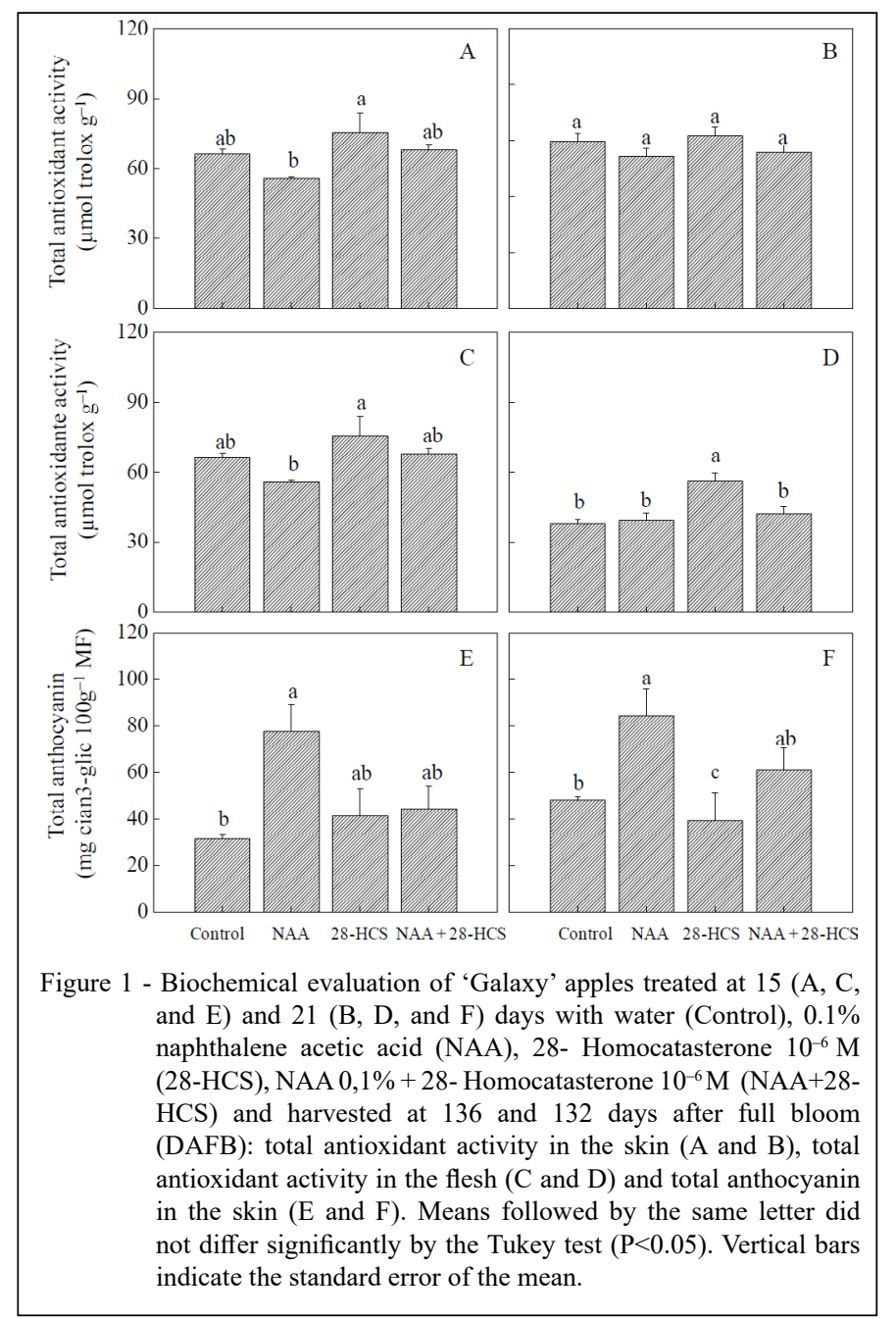

fruits. Antioxidants are substances with the ability to dissipate and/or reduce ROS and contribute towards the maintenance of fruit quality. Since we demonstrated that 28-HCS application is able to enhance TAA in "Galaxy" apples, it is reasonable to consider that this BR might be useful to contribute to the maintenance of fruit quality and consequently conservation of 'Galaxy' apples.

The TPC in the skin was not affected by the phytoregulators (Figures 2A and 2B). However, bi-weekly applications of 28-HCS and NAA+28HCS enhanced TPC in the fruit flesh, when compared to control fruits (Figure 2C). In addition, fruits treated with NAA and 28-HCS every 15 days had lower $\mathrm{H}_{2} \mathrm{O}_{2}$ levels when compared to the other treatments (Figure 1E). For treatments applied every 21 days, only the single NAA treatment lowered $\mathrm{H}_{2} \mathrm{O}_{2}$ content (Figure $2 \mathrm{~F})$. At $136 \mathrm{DAFB}$, fruits treated every 15 days with 28 -HCS and NAA +28 -HCS showed lower malonaldehyde levels, an indicative of membrane lipid peroxidation (Figure 3A). Fruits treated with 28-HCS presented higher peroxidase activity (Figure $3 \mathrm{~B}$ ), while SOD activity was lower in the NAA + 28-HCS-treated fruits, when compared to the other treatments (Figure 3C).

Higher malonaldehyde content indicates higher degree of lipid peroxidation at the plasma membrane level. In the membrane, oxygen peroxidation takes place due to the accumulation of some ROS, such as $\mathrm{H}_{2} \mathrm{O}_{2}$, singlet oxygen, superoxide and hydroxyl radicals, which induce oxidative damage in the plant cell membranes (OGWENO et al., 2008). In order to remove the ROS, plants increase activity of antioxidative stress enzymes like catalase, POD and SOD, besides inducing activity of antioxidant compounds. SOD is the first line of enzyme defense 


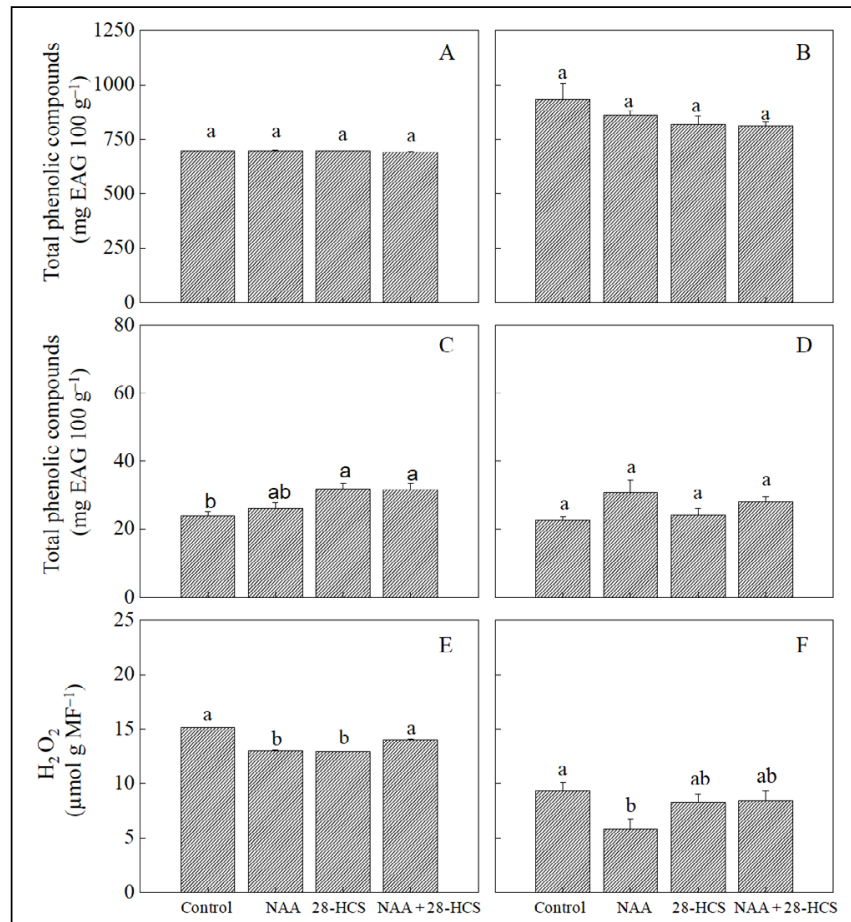

Figure 2 - Biochemical evaluation of the 'Galaxy' apples treated every 15 (A, C, and E) and 21 (B, D, and F) days with water (Control), $0.1 \%$ naphthalene acetic acid (NAA), 28- Homocatasterone $10^{-6} \mathrm{M}\left(28\right.$-HCS), NAA $0,1 \%+28$ - Homocatasterone $10^{-6}$ $\mathrm{M}(\mathrm{NAA}+28-\mathrm{HCS})$ and harvested at 136 and 132 days after full bloom (DAFB): the total phenolic compounds in the skin (A and B); total phenolic compounds in the flesh (C and D), hydrogen peroxide concentration $\left(\mathrm{H}_{2} \mathrm{O}_{2}\right)(\mathrm{E}$ and $\mathrm{F})$. Means followed by the same letter do not differ significantly by the Tukey test $(\mathrm{P}<0.05)$. Vertical bars indicate the standard error of the means.

against ROS as it has the capacity to convert the superoxide anion $\left(\mathrm{O}^{2-}\right)$ into $\mathrm{H}_{2} \mathrm{O}_{2}$. However, $\mathrm{H}_{2} \mathrm{O}_{2}$ is a highly toxic compound that also needs to be removed. Peroxidases help to convert $\mathrm{H}_{2} \mathrm{O}_{2}$ to $\mathrm{H}_{2} \mathrm{O}$, also contributing to the complete removal of the ROS. Another line of defense for the dissipation of ROS is the increase in the concentration of phenolic compounds in the fruits. The ripening process and senescence are oxidative phenomena and $\mathrm{O}^{2-}, \mathrm{H}_{2} \mathrm{O}_{2}$, hydroxyl radical $\left(\mathrm{OH}^{-}\right)$, peroxy radical ( $\left.\mathrm{ROO}-\right)$ and singlet oxygen $\left(\mathrm{O}_{2}\right)$ are the main ROS which cause oxidative fruit damage (BHATTACHARJEE, 2005). Results from this study indicated that 28-HCStreated fruits have a lower lipid peroxidation in the plasma membrane due to the decreased $\mathrm{H}_{2} \mathrm{O}_{2}$, which is produced by the increased action of peroxidase. The ROS reduction retards ripening and senescence, besides helping on the maintenance of post-harvest fruit quality. When growth regulators are applied together they can act antagonistically, as observed in this study (Figure $3 \mathrm{C}$ ), where the associated use of NAA + 28-HCS decreased SOD activity compared to the other treatments.

\section{CONCLUSION}

The bi-weekly applications of 28HCS resulted in increased total soluble solids and maintenance of the skin rupture force of the 'Galaxy' apple fruits. Furthermore, 28-HCS also boosted antioxidant activity in the skin and flesh, as well as it increased peroxidase activity, which might result in reduced degree of oxidative damage to the fruit plasma membranes. In addition, NAA applications every 21 days decreased starch content, titratable acidity, and color attribute $h$ in the fruit skin. However, application 


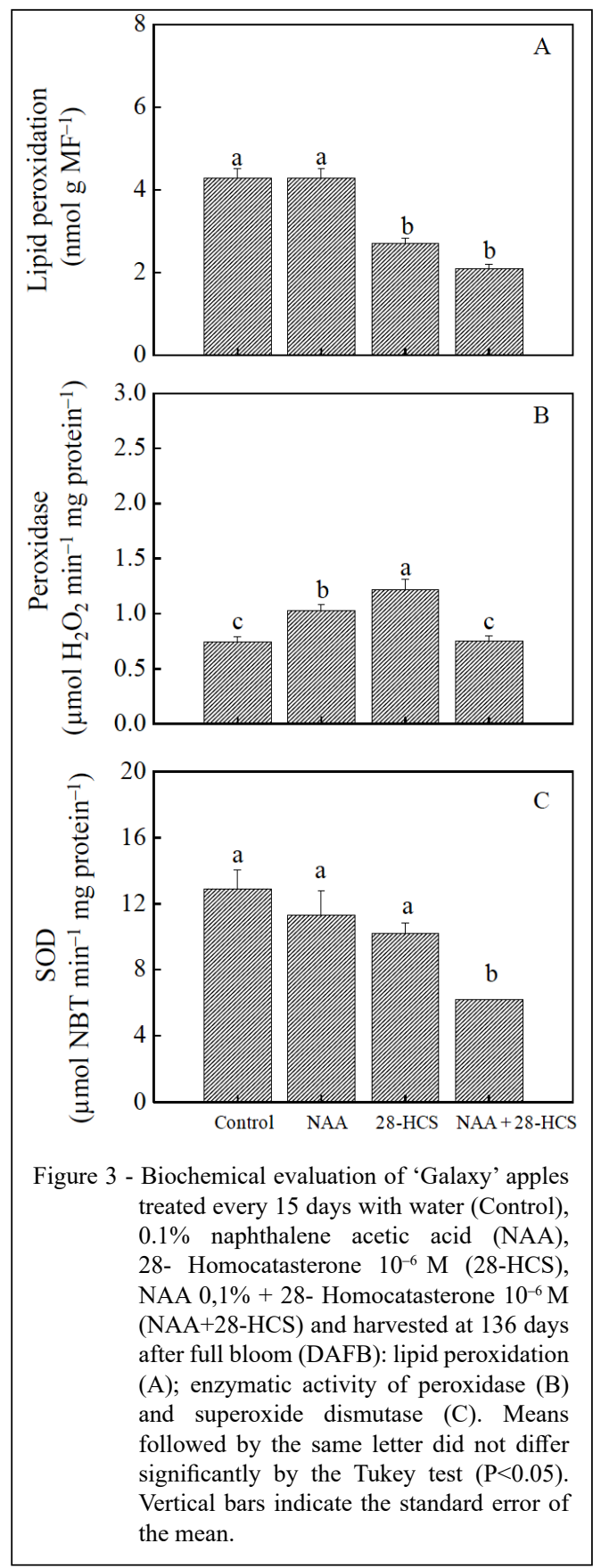

of NAA every 15 or 21 days was reported to increase anthocyanin level in the skin of the 'Galaxy' apples.

\section{ACKNOWLEDGEMENTS}

The authors express their thanks to the Coordenação de Aperfeiçoamento de Pessoal de Nível Superior (CAPES) for the academic master's exchange grant. This study was financed in part by the Coordenação de Aperfeiçoamento de Pessoal de Nível
Superior - Brasil (CAPES) - Finance Code 001. We also thank the Santa Catarina State University for making the infrastructure available for us to carry out this study.

\section{DECLARATION OF CONFLICT OF INTEREST}

The authors declare no conflict of interest. The founding sponsors had no role in the design of the study; in the 
collection, analyses, or interpretation of data; in the writing of the manuscript, and in the decision to publish the results.

\section{AUTHORS' CONTRIBUTIONS}

The authors contributed equally to the manuscript.

\section{REFERENCES}

AMARANTE, C.V.T. et al. Prediction of bitter pit in 'Gala' apples through the infiltration of fruits with magnesium. Brazilian Journal of Fruit Crops, v.31, n.4, p.962-968, 2009. Available from: $<$ http://www.scielo.br/pdf/rbf/v31n4/v31n4a08.pdf>. Accessed: Apr. 07, 2018. doi: 10.1590/S0100-29452009000400008.

BAJGUZ, A. Effect of brassinosteroids on nucleic acid and protein content in cultured cells of Chlorella vulgaris. Plant Physiology and Biochemistry, v.38, p.209-215, 2000. Available from: <https://www.sciencedirect.com/science/article/pii/ S0981942800007336>. Accessed: Apr. 04, 2018. doi: 10.1016 / S0981-9428 (00) 00733-6.

BALBI, V. et al. Regulation of early tomato fruit development by the Diageotropica gene. Plant Physiology, v.131, p.186-197, 2003. Available from: <https://www.ncbi.nlm.nih.gov/pmc/ articles/PMC166799/>. Accessed: Apr. 10, 2018. doi: 10.1104/ pp.010132.

BARTLETT, M.S. Properties of sufficiency and statistical tests. Proceedings of the Royal Society of London, v.160, p.268-282, 1937. Available from: <http://rspa.royalsocietypublishing.org/ content/160/901/268>. Accessed: Apr. 15, 2018. doi: 10.1098 rspa.1937.0109.

BHATTACHARJEE, S. Reactive oxygen species and oxidative burst: roles in stress, senescence and signal transduction in plants. Current Science, v.89, p.1113-1121, 2005. Available from: $<$ http://www.jstor.org/stable/24110963?seq=1\#page_scan_tab_ contents>. Accessed: Apr. 07, 2018.

CAO, S. et al. Loss-of-function mutations in DET2 gene lead to an enhanced resistance to oxidative stress in Arabidopsis. Physiology Plantarum, v.123, p.57-66, 2005. Available from: <https:// onlinelibrary.wiley.com/doi/abs/10.1111/j.1399-3054.2004.00432. x>.Accessed:Apr. 09, 2018. doi: 10.1111/j.1399-3054.2004.00432.x.

DEL LONGO, O.T. et al. Antioxidant defenses under hyper oxygenic and hyperosmotic conditions in leaves of two lines of maize with differential sensitivity to drought. Plant and Cell Physiology, v.34, p.1023-1028, 1993. Available from: <https:// academic.oup.com/pcp/article-abstract/34/7/1023/1810685>. Accessed: Apr. 05, 2018. doi: 10.1093/oxfordjournals.pcp. $\mathrm{a} 078515$.

FULEKI, T.; FRANCIS, F.J. Quantitative methods for anthocyanins: extraction and determination of total anthocyanin in cranberries. Journal of Food Science, v.33, p.72-77, 1968. Available from: <https://onlinelibrary.wiley.com/doi abs/10.1111/j.1365-2621.1968. tb00887.x>. Accessed: Apr. 05, 2018. doi: $10.1111 /$ j.1365-2621.1968.tb00887.x.

HEATH, R.L.; PACKER, L. Photoperoxidationin isolated chloroplasts. I. Kinetics and stoichiometry of fatty acid peroxidation. Archives of Biochemistry and Biophysics, v.125, p.189-198, 1968. Available from: <https://www.sciencedirect. com/science/article/pii/0003986168906541>. Accessed: Apr. 05, 2018. doi: 10.1016/0003-9861(68)90654-1.

HERMES-LIMA, M. et al. Quantification of lipid peroxidation in tissue extracts based on Fe (III) xylenol orange complex formation. Free Radicals in Biology and Medicine, v.19, p.271-280, 1995. Available from: <https://www.sciencedirect.com/science/article/ pii/089158499500020X?via\%3Dihub>. Accessed: Apr. 05, 2018. doi: 10.1016/0891-5849(95)00020-X.

KAR, M.; MISHRA, D. Catalase, peroxidase, and polyphenoloxidase activities during rice leaf senescence. Plant Physiology, v.57, p.315-319, 1976. Available from: $<$ https://www. ncbi.nlm.nih.gov/pmc/articles/PMC542015/>. Accessed: Mar. 25, 2018. doi: 10.1104/pp.57.2.315.

LIN-WANG, K. et al. High temperature reduces apple fruit color via modulation of the anthocyanin regulatory complex. Plant, Cell \& Environment, v.34, p.1176-1190, 2011. Available from: <https://onlinelibrary.wiley.com/doi/abs/10.11 11/j.1365-3040.2011.02316.x>. Accessed: Mar. 04, 2018. doi: 10.1111/j.1365-3040.2011.02316.x.

LIU, Q. et al. Vacuole integrity maintained by DUF300 proteins is required for brassinosteroid signaling regulation. Molecular Plant, v.11, p.553-567, 2018. Available from: <http://www.cell.com/ molecular-plant/fulltext/S1674-2052(17)30385-4>. Accessed: Apr. 07, 2018. doi: 10.1016/j.molp.2017.12.015.

MIQUELOTO, A. Ação das auxinas na funcionalidade do xilema e ocorrência de "bitter pit" em maçãs. 2015. 55f. Tese (Doutorado em Fisiologia Vegetal) - Universidade Federal de Viçosa, Viçosa.

MOTERLE, L.M. et al. Efeito de biorregulador na germinação e no vigor de sementes de soja. Revista Ceres, v.58, p.651660, 2011. Available from: <http://www.scielo.br/scielo. php?script $=$ sci_arttext\&pid $=$ S0034-737X2011000500017\&lng $=$ en $\& n r m=$ iso $>$. Accessed: Apr. 07, 2018. doi: 10.1590/S0034737X2011000500017.

NAGATA, N. et al. Brassinazole, an inhibitor of brassinosteroid biosynthesis, inhibits development of secondary xylem in cress plants (Lepidium sativum). Plant Cell Physiology, v.42, p.1006-1011, 2001. Available from: <https://www.researchgate. net/publication/11771652_Brassinazole_an_Inhibitor_of Brassinosteroid Biosynthesis Inhibits Development of Secondary_Xylem_in_Cress_Plants_Lepidium_sativum $>$. Accessed: Āpr. 10, 2018. doi: 10.1093/pc̄p/pce122.

OGWENO, J.O. et al. Brassinosteroids alleviate heat-induced inhibition of photosynthesis by increasing carboxylation efficiency and enhancing antioxidant systems in Lycopersicon esculentum. Journal of Plant Growth Regulation, v.27, p.49-57, 2008. Available from: <https://link.springer.com/article/10.1007/ s00344-007-9030-7>. Accessed: Apr. 15, 2018. doi: 10.1007/ s00344-007-9030-7.

PETRI, J.L. et al. Advances in apple tree culture in Brazil. Revista Brasileira de Fruticultura, v.33, p.48-56, 2011. Available from: $<$ http://www.scielo.br/scielo.php?script $=$ sci_arttext\&pid $=$ S010029452011000500007\&lng=en\&nrm=iso $>$. Accessed: Apr. 07, 2018. doi: 10.1590/S0100-29452011000500007.

RE, R. et al. Antioxidant activity applying an improved ABTS radical cation decolorization assay. Free Radical Biology 
and Medicine, v.26, p.1231-1237, 1999. Available from: $<$ https://www.sciencedirect.com/science/article/pii/ S0891584998003153?via\%3Dihub>. Accessed: Sep. 26, 2018. doi: 10.1016/S0891-5849(98)00315-3.

\section{SAS INSTITUTE. Getting started with the SAS learning} edition. Cary: SAS, 2009. 200p.

SHAPIRO, S.S.; WILK, M.B. An analysis of variance test for normality (complete samples). Biometrika, v.52, p.591611, 1965. Available from: <https://www.jstor.org/stable/ 2333709?seq=1\#metadata_info_tab_contents $>$. Accessed: Mar. 20, 2018. doi: $10.2307 / 2333709$.

TAIZ, L.; ZEIGER, E. Plant physiology. 5nd ed. Sunderland: Sinauer Associates, Inc., Publishers, 2013. 793p.

TNAAKA, Y. et al. Flower color modification by engineering of the flavonoid biosynthetic pathway: Practical perspectives. Bioscience, Biotechnology, and Biochemistry, v.74, p.1760 1769, 2010. Available from: <https:/www.tandfonline.com/doi/ abs/10.1271/bbb.100358>. Accessed: Apr. 06, 2018. doi: 10.1271/ bbb. 100358 .

THEWES, F.R. et al. Dynamic controlled atmosphere and ultralow oxygen storage on 'Gala' mutants quality maintenance. Food Chemistry, v.188, p.62-70, 2015.
Available from: <https:/www.sciencedirect.com/science/article/ pii/S0308814615006858?via\%3Dihub>. Accessed: Apr. 07, 2018. doi: 10.1016/j.foodchem.2015.04.128.

WERNER, R.A. Current status of controlled atmosphere storage in Brazil. In: International Controlled Atmosphere Research Conference, 5, Wenatchee, Washington, 1989. Proceedings... Wenatchee, Washington, v.1, p.509-515, 1989.

$\mathrm{XU}$, F. et al. Brassinosteroids are involved in controlling sugar unloading in Vitis vinifera 'Cabernet Sauvignon' berries during véraison. Plant Physiology and Biochemistry, v.94, p.197-208, 2015. Available from: <https://www.sciencedirect.com/science/ article/pii/S0981942815300358?via\%3Dihub>. Accessed: Apr. 01, 2018. doi: 10.1016/j.plaphy.2015.06.005.

YOKOTA, T. The structure, biosynthesis and function of brassinosteroids. Trends in Plant Science, v.2, p.137-143, 1997. Available from: <https://www.sciencedirect.com/science/article/ pii/S1360138597010170>. Accessed: Sep. 01, 2018. doi: 10.1016/ S1360-1385(97)01017-0.

YU, Y.B.; YANG, S.F. Auxin-induced ethylene production and its inhibition by aminoethoxyvinylglycine and cobalt ion. Plant Physiology, v.64, p.1074-1077, 1979. Available from: <https:// www.ncbi.nlm.nih.gov/pmc/articles/PMC543194/>. Accessed: Aug. 09, 2018. 